\title{
WHAT DOES THE TERM TOGATA 'REALLY' MEAN?
}

\begin{abstract}
This article aims to shed fresh light on the meaning of the term togata. It conducts an analysis of the term as it appeared in ancient sources, ${ }^{1}$ investigating in particular both how and why ancient authors across several periods focussed their attention on the togata. The paper will also distinguish between the attestation of the term togata in ancient writers, who are likely to have actually watched these theatrical performances in person and known more directly what they were talking about, and the usage of the term by later grammarians, who would have had no opportunity to watch such performances. These later authors, rather, were simply guessing what kind of theatrical representation could have been performed onstage (much as we do nowadays) and did so by adopting obvious differences in terminology.
\end{abstract}

Keywords: togata; Roman drama; terminology; ancient sources

The togata has traditionally been defined as comedy in Roman dress, settings and onomastics, ${ }^{2}$ in comparison with and opposition to the (comoedia/fabula) palliata, that is, comedy in Greek dress, ${ }^{3}$ because the term, of course, alludes to the toga, the formal garment of Roman civilians, which was worn by actors on stage. ${ }^{4}$ The now fragmentary corpus which makes up this literary genre is attributed-not always unproblematically - to Titinius, Afranius and Atta, all of whom are mentioned by ancient writers as togata playwrights. This genre developed between the second and first centuries B.C.E. and may well have declined "not because of its own inherent faults, its Menandrism and an increasing seriousness that was not appreciated by the mass of spectators, but, like other dramatic genres, rather owing to the overall situation of dramatic performances at the time' ${ }^{5}$

* I would like to thank the two anonymous referees for their invaluable comments on the first draft of this paper, which enabled me to improve it both methodologically and stylistically. I would likewise like to thank Carrie La Rocco and Henry Stead for helping me edit my paper.

${ }^{1}$ I consider the ancient sources in which the term togata means 'theatrical representation' rather than 'dressed in a toga' (e.g. Gallia in Suet. Gram. et rhet. 3.6.3 and Pomponius Mela, De chorographia 2.59.3; and people in Mart. 6.48.1 and Prop. 4.2.56).

2 Cf. e.g. G. Manuwald, 'Plautus and Terence in their Roman contexts', in M.T. Dinter (ed.), The Cambridge Companion to Roman Comedy (Cambridge, 2019), 17-31, at 23: 'Roman-style comedy ( fabula togata) representing everyday events of ordinary people set in Rome'.

3 As G. Manuwald, Roman Republican Theatre (Cambridge, 2011), 158 mentioned, the togata 'was understood as a reaction to the growing Hellenization and eventual decline of palliatae', citing in footnote 97 some scholars who have supported this thesis: for example J.H. Neukirch, De fabula togata Romanorum: accedunt fabularum togatarum reliquiae (Leipzig, 1833), 66; E. Courbaud, De comoedia togata (Paris, 1899), 17-27; M. Cacciaglia, 'Ricerche sulla fabula togata', RCCM 14 (1972), 207-45, at 207-8. See also Manuwald (n. 2), 23.

${ }^{4}$ See, for instance, W. Beare, The Roman Stage. A Short History of Latin Drama in the Time of the Republic (London, 1964 $4^{3}$ ), 254. Cf. also e.g. A. López, "El adjetivo "togatus" y la comedia "togata", Helmantica 28 (1977), 331-42, reprinted in A. López and A. Pociña (edd.), Estudios sobre comedia romana (Frankfurt and Berlin, 2000), 341-53.

5 Manuwald (n. 3), 168-9.

(C) The Author(s), 2021. Published by Cambridge University Press on behalf of The Classical Association. This is an Open Access article, distributed under the terms of the Creative Commons Attribution licence (http:// creativecommons.org/licenses/by/4.0/), which permits unrestricted re-use, distribution, and reproduction in any medium, provided the original work is properly cited. 
Analysis of ancient sources referring to the togata shows how different authors perceived and described the theatrical category: this could be due to the contradictory nature of these ancient sources, as Wiseman has observed, ${ }^{6}$ as well as to different systems of nomenclature, as Manuwald has pointed out. ${ }^{7}$

Here, I do not assume that all the ancient sources refer to the same thing. Furthermore, given the variable validity of the sources, I call into question their being attributed equal weight. In other words, my main aim is to reopen the togata file. I shall begin by analysing the ancient sources for togatae written by those who might actually have seen them, or at least were more likely to have been well informed about them, having been alive when they were being performed. In the second part of this article, I shall investigate the dramatic classification made by later writers, who delved into the nomenclature of the togata alongside other literary genres of the Mid Republic.

\section{I.1. Cicero}

Let us begin with Cic. Sest. $118,{ }^{8}$ the earliest attestation of the word togata:

sed quid ego populi Romani animum uirtutemque commemoro, libertatem iam ex diuturna seruitute dispicientis, in eo homine cui tum petenti iam aedilitatem ne histriones quidem coram sedenti pepercerunt? nam cum ageretur togata 'Simulans', ut opinor, caterua tota clarissima concentione in ore impuri hominis imminens contionata est:

$$
\begin{aligned}
& \text { huic, Tite, } \\
& \text { tua post principia atque exitus uitiosae uitae-! }
\end{aligned}
$$

sedebat examinatus, et is, qui antea cantorum conuicio contiones celebrare suas solebat, cantorum ipsorum uocibus eiciebatur. et quoniam facta mentio est ludorum, ne illud quidem praetermittam, in magna uarietate sententiarum numquam ullum fuisse locum, in quo aliquid a poeta dictum cadere in tempus nostrum uideretur, quod aut populum uniuersum fugeret aut non exprimeret ipse actor. ${ }^{9}$

Cicero mentions a togata on stage in 57 B.C.E. As Cicero was in exile during this period, ${ }^{10}$ he could not have watched the play himself, but possibly knew something about it from others.

6 T.P. Wiseman, Unwritten Rome (Exeter, 2008), especially 195.

${ }^{7}$ Manuwald (n. 3), especially 156-8.

${ }^{8}$ On Cicero's Pro Sestio, cf. e.g. D. Schmitz, 'Rhetorik in Praxis und Theorie: Cicero, Pro Sestio/ De Inventione', Der Altsprachliche Unterricht: Latein, Griechisch 38 (1995), 41-53; E. Flores, 'L'orazione Pro Sestio di Cicerone', Vichiana 13 (2011), 91-4.

9 Transl. G. Manuwald, Roman Drama. A Reader (London, 2010), 71: 'But why should I recall the Roman people's spirit and courage, when they were just discerning liberty after long servitude, in the case of this man, whom not even the actors have spared, when he was already a candidate for the aedileship and sitting before them? For when a togata, entitled Simulans ('The Pretender'), I believe, was being performed, the whole group of actors publicly harangued him in splendid harmony, bending towards the face of the polluted man: "This, Titus, is the sequel for you and the outcome of your vicious life!" He sat there entirely put out of his senses, and he who previously used to fill his popular assemblies with abuse of hired singers was now driven off by the voices of actual singers. And since mention has been made of the games, I will not omit this detail, namely that amid the great variety of utterances there has never been a passage in which something said by the poet seemed to apply to our time that either escaped the whole populace or was not expressed by the actor himself.'

10 See G. Petrone, 'Lo spazio delle emozioni teatrali, tra storiografia e politica, secondo la testimonianza

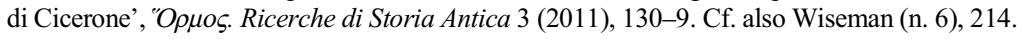


The play, entitled Simulans, on the basis of a fragment attested by Antonius Panurgus, ${ }^{11}$ can be attributed to the playwright Afranius. During this performance, the aforementioned fragment huic, Tite, | tua post principia atque exitus uitiosae uitae was pronounced against Clodius, ${ }^{12}$ who sat dispirited and humiliated. ${ }^{13}$ Beyond the political implications of these lines, ${ }^{14}$ the meaning of the term togata is difficult to understand. The expression cum ageretur togata suggests that Cicero was talking about something his audience was familiar with; consequently, he did not consider it necessary to clarify further. In any case, the mention of the term togata here is provocative: Cicero might just as easily have written comoedia. His preference for togata suggests a desire to emphasize the term but to what end? He might have deliberately used the word to differentiate togata from other Mid Republican literary genres, such as the palliata and the praetexta. The quotation of Afranius' lines, the use of the Roman name Titus - not attested in the palliata, where we find instead Greek and invented names - and, above all, the usage of the term togata itself suggest that Cicero was alluding to something far removed from the Greek world and more closely related to the Latin world; for these reasons, he used the term togata to refer to the play Simulans.

\section{I.2. Varro}

In his De lingua Latina, Varro reports that a togata was staged in the city of Rome during the Ludi Apollinares (Ling. 6.18-19):

Nonae Caprotinae, quod eo die in Latio Iunoni Caprotinae mulieres sacrificant et sub caprifico faciunt; e caprifico adhibent uirgam. cur hoc, togata praetexta data eis Apollinaribus Ludis docuit populum. ${ }^{15}$

Given that Varro refers to the Ludi Apollinares, it is clear that a togata $^{16}$ was performed in Rome. ${ }^{17}$ Here, Varro uses togata as a general term to be qualified by the

11 The grammarian Antonius Panurgus in a fragment quoted by Festus page 174 Lindsay lists a series of authors and their plays. He refers to Afranius' Simulans.

${ }^{12}$ This was not a unique occasion. Cicero reports that tragic verses were also used against Pompey during the Ludi Apollinares (cf. Cic. Att. 2.19.3). See also R.A. Kaster, Speech on behalf of Publius Sestius. Marcus Tullius Cicero. Translated with Introduction and Commentary (Oxford and New York, 2006), 350.

13 See R.C. Beacham, The Roman Theatre and its Audience (London, 1991), 160.

14 On popular criticism of Clodius in those years, cf. Kaster (n. 12), 1-40.

15 Transl. W.D.C. de Melo, Varro: De lingua Latina. Introduction, Text, Translation, and Commentary, 2 vols. (Oxford, 2019), 367: "The Nonae Caprotinae "Nones of Caprotina" got their name because on that day the women sacrifice to Iuno Caprotina in Latium, and they do so under a caprificus "wild fig tree"; from the fig tree they use a branch. As to why this was done, the praetexta play presented to them at the games for Apollo has taught the people.'

${ }_{16}$ The word transmitted in the manuscripts is togata, but scholars have suggested reading toga instead: see e.g. A. Traglia, Opere di M. Terenzio Varrone (Turin, 1974), 189; F. Coarelli, Il campo Marzio dalle origini alla fine della repubblica (Rome, 1997), 38-9 and 55. On the other hand, G. Manuwald, Fabulae praetextae. Spuren einer literarischen Gattung der Römer (Munich, 2001), 24-9 rejects the term toga and argues that togata is the most acceptable form. See also Wiseman (n. 6), 194 who argues that 'Varro refers to a play that is both. That is because Varro had his own categorisation of dramatic forms.' M. Meulder, 'Varron, De lingua latina 6, 18-19: "toga praetexta", “togata praetexta", ou "togata, praetexta"?', Latomus 75 (2016), 862-87, at 865-7 tries to solve the above-mentioned philological issue by reading cur hoc togata, praetexta data eis, Apollinaribus ludis docuit populum. He suggests the following: a togata was staged; praetexta data is an absolute ablative rather than a nominative like togata; and a toga pratexta was given to women 'en récompense de leur conduite courageuse' (887).

${ }^{17}$ On this passage, cf. also A. Lesky, 'Fabula crepidata', RhM 95 (1952), 357-69, especially 361-2. 
specialization praetexta ${ }^{18}$ this suggests that Varro refers to a word which denotes 'generic category'. ${ }^{19}$ We do not actually know whether or not Varro watched this play; however, since togatae were still performed even in the Neronian era (see below), Varro might have had the chance to watch the play or at least to learn about the performance somehow. Varro not only focusses his attention on the representation of a togata in this passage but also (Ling. 5.25.8) reports that one of Afranius' togatae was performed:

(...) puticuli quod putescebant ibi cadauera proiecta, qui locus publicus ultra Exquilias. itaque eum Afranius puticulos in togata appellat, quod inde suspiciunt per puteos lumen. ${ }^{20}$

Varro explains the etymology of puticuli, reflecting on its geographical origin as well as mentioning a public place beyond the Esquiline called puticuli by the playwright Afranius. ${ }^{21}$ Accordingly, he identifies something linked to the city of Rome in this unknown togata, the meaning of which seems to be 'type of comedy', as de Melo has recently highlighted: 'The older usage would restrict togata to a type of Roman comedy not based on a Greek original, and here Varro is following this older usage. In the technical usage, where togata is a broader term, the kind of comedy not based on a Greek original would be called tabernaria (...)'. ${ }^{22}$

\section{I.3. Horace}

Horace, in the Ars poetica ${ }^{23}$ (Ars P. 285-91), appears to pay attention to the togata. He declares that the togata and the praetexta ${ }^{24}$ represented 'things done at home' in a sophisticated way that involves an elevated register; their authors, then, deserve to be celebrated:

nil intemptatum nostri liquere poetae, nec minimum meruere decus uestigia Graeca ausi deserere et celebrare domestica facta, uel qui praetextas uel qui docuere togatas. nec uirtute foret clarisue potentius armis quam lingua Latium, si non offenderet unum quemque poetarum limae labor et mora. ${ }^{25}$

\footnotetext{
18 Praetextae are attested in Rome from the time of Naevius (see e.g. Clastidium, Romulus/Lupus). After Naevius, authors such as Ennius, Pacuvius and Accius were involved in this literary genre; unfortunately, not a single praetexta has survived fully. On the praetexta, cf. e.g. Manuwald (n. 16); M. Erasmo, Roman Tragedy: Theatre to Theatricality (Austin, TX, 2004), 52-80; Manuwald (n. 3), 140-4.

19 See also de Melo (n. 15), 827.

20 Transl. de Melo (n. 15), 269: '(...) they are puticuli because the dead bodies thrown in putescebant "used to rot" there; this public burial place is beyond the Esquiline. Hence Afranius calls it the puticuli "pit-lights" in a togata play, because from there they look up at the lumen "light" through the putei.'

${ }_{21}$ On puteus, puteoli and puticuli, see de Melo (n. 15), 670.

22 de Melo (n. 15), 671.

${ }^{23}$ On the Ars poetica, see e.g. A. Laird, 'The Ars poetica', in S.J. Harrison (ed.), The Cambridge Companion to Horace (Cambridge, 2007), 132-43; P.R. Hardie, 'The Ars poetica and the poetics of didactic', MD 72 (2014), 43-54; P. Hajdú, 'Horace's Ars poetica as pure poetry', MD 72 (2014), 85-96.

24 As Wiseman (n. 6), 194 has remarked, 'Horace clearly implies that praetextae and togatae were not the same thing.'

${ }^{25}$ Transl. R.S. Kilpatrick, The Poetry of Criticism: Horace, Epistles II and Ars Poetica (Edmonton,
} 
Horace proudly says that Latin poets were involved in literary genres different from the Greek ones. ${ }^{26}$ This reveals a competitiveness between Greek and Latin traditions, ${ }^{27}$ given that Latin poets focussed on matters with 'emotional overtones'. ${ }^{28}$ Moreover, as Petrone has highlighted, Horace's reference to the term togata in this passage is intriguing because it suggests how such a theatrical genre was not far removed from the onstage representation of 'motivi di riflessione sul costume patrio e sui comportamenti morali'. ${ }^{29}$ However, the meaning of togata deserves attention: indeed, the line uel qui praetextas uel qui docuere togatas alluding to the staging of praetexta and togata 'is more difficult than it seems because the meaning of these terms is not agreed'. ${ }^{30}$ That is, it is not possible to be sure about the meaning of the term togata here, whether it was meant as comedy - and thus in comparison with, and in opposition to, praetexta - or should rather be interpreted as a generic theatrical category, mistakenly meant as comedy, as mentioned by Diomedes (see below), who talks about communis error in the usage of the word togata in Horace's Ars poetica. ${ }^{31}$

\section{I.4. Seneca the Younger}

Since there is evidence to prove that togatae were still staged in Seneca's time, ${ }^{32}$ Seneca himself may well have watched these plays. In any case, Seneca is likely to have known what he was dealing with when he used the term togata. In his Letters, he appears to present a nuanced meaning of the term, treating togata as a kind of theatrical performance somewhere between comedy and tragedy. Indeed, in the eighth letter ${ }^{33}$ of his Epistulae morales ad Lucilium ${ }^{34}$ (8.8), Seneca reports that:

quam multi poetae dicunt, quae philosophis aut dicta sunt aut dicenda! non adtingam tragicos nec togatas nostras. habent enim hae quoque aliquid seueritatis et sunt inter comoedias ac tragoedias mediae. quantum disertissimorum uersuum inter mimos iacet! quam multa Publilii non excalceatis, sed coturnatis dicenda sunt! ${ }^{35}$

1990), 79: 'Our poets have left nothing untried, and not the least glory is due to those with the courage to abandon the Greeks' footsteps and celebrate things done at home, or produce either praetextae or togatae. Nor would Latium have greater might in virtue's field or arms' renown than with its tongue, if all our poets were not repelled by labour and patience with file.'

${ }^{26}$ Cf. C.O. Brink, Horace on Poetry. The 'Ars Poetica' (Cambridge, 1971), 318.

27 Cf. N. Rudd, Horace Epistles Book II and Epistle to the Pisones ('Ars Poetica') (Cambridge, 1989), 29.

28 Brink (n. 26), 319.

29 G. Petrone, 'La togata', in U. Albini and G. Petrone (edd.), Storia del Teatro. I Greci-I Romani (Milan, 1992), 473-84, at 473.

${ }^{30}$ Brink (n. 26), 319; see also 320.

31 See Lesky (n. 17), 358-9.

${ }^{32}$ For instance in Nero 11.2 Suetonius reports that Afranius' Incendium was staged in Rome, during the Ludi Maximi of Nero's time.

33 See e.g. C. Richardson-Hay, First Lessons. Book 1 of Seneca's Epistulae Morales - A Commentary (Bern, 2006), 271-2.

34 On the philosophical constructions in Seneca's Epistulae, see e.g. C. Star, Seneca (London and New York, 2017), 60; cf. also E. Schirok, 'Facere docet philosophia, non dicere! Brief 1 der "Epistulae morales" als programmatischer Einstieg', Der Altsprachliche Unterricht: Latein, Griechisch 55 (2012), 2-17; R. Badalì, 'Seneca "palombaro dell'anima umana", in R. Pesaresi (ed.), Cinque incontri sulla cultura classica (Lecce, 2015), 97-110; R. Früh, 'Verunsicherung im philosophischen Brief: Senecas Epistulae morales', in R. Früh, T. Fuhrer, M. Humar and M. Vöhler (edd.), Irritationem: Rhetorische und poetische Verfahren der Verunsicherung (Berlin and Boston, 2015), 87-108.

${ }^{35}$ Transl. adapted from M. Graver and A.A. Long, Seneca. Letters on Ethics to Lucilius (Chicago and London, 2015), 39: 'So many poets say things that philosophers have said, or that they ought to have said! I need not refer to the tragedians or to the authors of our togatae (for those plays too have a 
Seneca discusses wisdom and poets. ${ }^{36}$ By using the expression inter comoedias ac tragoedias, he alludes to a theatrical genre between comedy and tragedy, perhaps a play with elements belonging to both theatrical traditions, in which it is possible to find aliquid seueritatis. ${ }^{37}$ Here, the use of the adjective nostrae is attention-grabbing: togatae nostrae could refer to the fact that Seneca acknowledged the belief that these plays were not based on Greek originals, and perhaps aimed to emphasize a totally Roman literary genre. Also of interest is another passage of Seneca, namely Ep. 89.7:

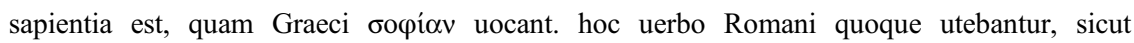
philosophia nunc quoque utuntur. quod et togatae tibi antiquae probabunt et inscriptus Dossenni monumento titulus: Hospes resiste et sophian Dossenni lege. ${ }^{38}$

Seneca mentions both togatae and philosophy: in the togatae there were elements of Roman sapientia defined as perfectum bonum mentis humanae (89.4). This definition is reminiscent of Stoic ethics ${ }^{39}$ and links the discussion of philosophical questions to the togatae, which would include traits of popular wisdom, viewed as a guide for life, and the model of the perfect sage. In this way, Seneca's testimony highlights wisdom as one of the togata themes and a goal which is to be put into practice every day. ${ }^{40}$ Furthermore, such a topic might be shared by togatae antiquae and Atellanae: Dossennus is the name of the smart hunchback of the (fabula) Atellana, ${ }^{41}$ though it is not certain whether Seneca is making reference to this character here. The reference to philosophical issues in the togata, according to the parallelism put forward by Seneca, prompts us to briefly analyse the extant fragments for hints of these themes. Closer scrutiny of the remaining fragments of the togata would confirm the presence of philosophical themes connected with popular wisdom and Stoic ethics, since we read, for instance, in Afranius 23-4 $\mathrm{R}^{3}$ alius est Amor, | alius Cupido ${ }^{42}$ and in Afranius $221 \mathrm{R}^{3}$ amabit

serious element; they are in between tragedy and comedy). Plenty of highly eloquent verses are to be found even in the mime. Many lines of Publilius are such as would befit not only the writer of comedy but even the tragedian.'

36 See also Lesky (n. 17), 360.

37 On this, cf. F. Leo, Geschichte der römischen Literatur (Berlin, 1913), 378.

38 Transl. adapted from Graver and Long (n. 35), 320: 'Sophia is actually the Greek word for "wisdom". Romans too used to speak of sophia, just as we still use the Greek word philosophia. You have evidence for this in our old theatrical representations and in the inscription of the tomb of Dossennus: "Stop, traveller, and read the Sophia of Dossennus".' On this passage, see T. Baier, "Metateatralità nella "fabula togata", in G. Petrone and M.M. Bianco (edd.), Comicum choragium. Effetti di scena nella commedia antica (Palermo, 2010), 77-87, at 83-4. Cf. also V. Ussani Jr., 'Per la storia del teatro latino. II. Seneca e la commedia togata', GIF 21 (1969), 375-410.

39 A.A. Long, 'Roman philosophy', in D. Sedley (ed.), The Cambridge Companion to Greek and Roman Philosophy (Cambridge, 2005), 184-210, especially 203-6; see also Graver and Long (n. 35), 13.

${ }^{40}$ On the relationship between Stoicism and Seneca's philosophy, see e.g. Star (n. 34), 25-33.

${ }^{41}$ On the Atellana, cf. e.g. G.E. Duckworth, The Nature of Roman Comedy (Princeton, 1952), 10-13; P. Frassinetti, Fabula Atellana. Saggio sul teatro popolare latino (Genoa, 1953); Beare (n. 4), 137-48; C. Panayotakis, 'Comedy, Atellane farce and mime', in S. Harrison (ed.), $A$ Companion to Latin Literature (Malden and Oxford, 2005), 130-47; W.D.C. de Melo, 'The language of Atellan farce', in R. Raffaelli and A. Tontini (edd.), L'Atellana letteraria. Atti della prima giornata di studi sull'Atellana. Succivo (CE) 30 ottobre 2009 (Urbino, 2010), 121-55; E. Lefèvre, 'Atellana e palliata: gli influssi reciproci', in R. Raffaelli and A. Tontini (edd.), L'Atellana letteraria. Atti della prima giornata di studi sull'Atellana. Succivo (CE) 30 ottobre 2009 (Urbino, 2010), 15-36; Manuwald (n. 3), 169-77; C. Panayotakis, 'Native Italian drama and its influence on Plautus', in M.T. Dinter (ed.), The Cambridge Companion to Roman Comedy (Cambridge, 2019), 32-46.

42 'One is Love, another is Desire.' The fragments of the togata are quoted in the edition of 
sapiens, cupient ceteri. ${ }^{43}$ Whoever the speaker is, both lines can be interpreted as having Stoic undertones, given the distinction between the 'wise person' and 'all others'. Stoic definitions of erōs usually avoid defining the term as a type of desire (epithumia denotes a morally and intellectually defective passion), precisely so that they can say that the good/ wiser person experiences erōs without experiencing desire. ${ }^{44}$ Also worth mentioning is Titinius 127-8 $\mathrm{R}^{3}$ Sapientia gubernator nauem torquet, non ualentia: cocus magnum ahenum, quando feruuit, paula confutat trua, ${ }^{45}$ in which there is mention of a gubernator being inspired by Sapientia in what he does. ${ }^{46}$ Finally, we find a kind of comparison between the way in which the Greeks and the Romans are accustomed to naming 'wisdom' in Afranius 298-9 R R $^{3}$ sus me genuit, mater peperit Memoria: | Sophiam uocant me Grai, uos Sapientiam. ${ }^{47}$ References to philosophical topics and issues in the remains of the togata may thus confirm Seneca's suggestions about the allusions to philosophical topics in the old togatae, especially Stoic ethics. ${ }^{48}$ Therefore, the presence of philosophical suggestions within the togatae that Seneca might have watched and/or read could be at the heart of his statement. That is to say, the seriousness of some togatae may have suggested to Seneca that these togatae were a theatrical category between comedy and tragedy.

\section{I.5. Quintilian}

Before investigating the complex grammatical tradition on the togata (quoted along with other dramatic genres of the Mid Republic), in this section I analyse an important passage of Quintilian (Inst. 10.1.99-100), in which the playwright Afranius is mentioned because of his excellence in togatae:

in comoedia maxime claudicamus. licet Varro Musas, Aeli Stilonis sententia, Plautino dicat sermone locuturas fuisse si Latine loqui uellent, licet Caecilium ueteres laudibus ferant, licet Terenti scripta ad Scipionem Africanum referantur (quae tamen sunt in hoc genere elegantissima, et plus adhuc habitura gratiae si intra uersus trimetros stetissent), uix leuem consequimur umbram, adeo ut mihi sermo ipse Romanus non recipere uideatur illam solis concessam Atticis uenerem, cum eam ne Graeci quidem in alio genere linguae optinuerint. togatis excellit Afranius. utinam non inquinasset argumenta puerorum foedis amoribus, mores suos fassus! ${ }^{49}$

O. Ribbeck, Scaenicae Romanorum poesis fragmenta. Vol. II. Comicorum Romanorum praeter Plautum et Syri quae feruntur sententias fragmenta (Leipzig, $1898^{3}$ ).

43 'A wise person will love, the rest will desire.'

${ }^{44}$ Cf. e.g. Stob. SVF 3.395, 650 and 717 (lines 33-5); Cic. Tusc. 4.72 and the distinctions between kinds of erōs in Stob. SVF 3.397. For a different view, see Diog. Laert. 7.113.

45 'With wisdom the helmsman twists the ship, not with strength; the cook keeps the big bronze pot from boiling over, when it boils, with a small ladle.'

${ }^{46}$ On this fragment, A. Minarini, 'Il linguaggio della togata tra innovazione e tradizione', BStudLat 27 (1997), 34-55, at 44-5.

47 'Experience generated me. Memory is the mother who gave birth to me: the Greeks call me Sophia, you Sapientia.'

${ }^{48}$ On the bond between New Comedy and philosophy, see e.g. R.L. Hunter, The New Comedy of Greece and Rome (Cambridge, 1985), 147-51.

49 Transl. adapted from D.A. Russell, Quintilian. The Orator's Education. Books 9-10 (Cambridge, MA and London, 2001), 307: 'It is in comedy that our steps most falter. True, Varro (quoting the view of Aelius Stilo) held that the Muses would have talked like Plautus if they had chosen to speak Latin; true, older critics extol Caecilius; true, Terence's works are attributed to Scipio Africanus (and they are in fact the most elegant of their kind, and would have possessed even more attraction if they had been written wholly in trimeters): nevertheless, we barely achieve a faint shadow, and I have come to think that the Latin language is incapable of acquiring that grace which was vouchsafed uniquely to the Athenians - for the Greeks too failed to achieve it in any other dialect of their language. In the togatae 
This passage occurs within a discussion related to Mid Republican drama. In Inst. 10.1.98, Quintilian mentions tragedies; he then refers to Latin comedies, quoting the most important authors of that period-above all, Plautus, with the famous remark that even Muses would have chosen to speak in Plautus' language. ${ }^{50}$ Quintilian shows his knowledge of the system of Roman drama, and lists tragedies, comedies and then togatae. With regard to the latter, he is not interested in the genre as a whole but only in Afranius, who was excellent in togatae. Here the term might probably refer to a theatrical genre between tragedies and comedies, as would be reasonable to suppose on the basis of the distinction Quintilian appears to make in his list, talking about tragedies, then comedies and afterwards togatae. There are however no additional clues as to what the author meant using the term togata in the passage, and thus every kind of further suggestions would be too speculative. In any case, Quintilian gives us an opportunity to observe the possible bond between the togata playwright and the Attic grace. He affirms that Latin language cannot acquire Attic grace, which characterized the Athenians, and that only Afranius was excellent enough in his plays to achieve that Attic grace. Sadly, according to Quintilian, it is a pity that he contaminated his plays with the onstage representation of pederasty. ${ }^{51}$

Let us now turn away from Cicero, Varro, Horace, Seneca and Quintilian, to investigate the grammarians and commentators who dealt with the togata in their works. On the basis of their interests as well as their standards of knowledge, they presumably aimed to improve the nomenclature related to the togata alongside other theatrical genres of the Mid Republic. The results of their discussions, however, as I shall show below, appear particularly problematic and nebulous.

II

\section{II.1. Diomedes}

To illustrate the semantic (and multivalent) significance of the word togata between later grammarians and commentators, I shall begin by focussing on a complex passage from Diomedes (Keil, Gramm. Lat. 1.489.14-19), who discusses different applications and meanings of dramatic terms such as togata, tabernaria and comoedia, and reports that:

initio togatae comoediae dicebantur, quod omnia in publico honore confusa cernebantur. quae togatae postea in praetextatas et tabernarias diuidebantur. togatae fabulae dicuntur quae scriptae sunt secundum ritus et habitum hominum togatorum, id est Romanorum (toga namque Romana est), sicut Graecas fabulas ab habitu aeque palliatas Varro nominari. togatas autem, cum sit generale nomen, specialiter tamen pro tabernariis non modo communis error usurpat,

the outstanding figure is Afranius. If only he had not defiled his plots with indecent paedophile intrigues, thereby exhibiting his own proclivities!'

${ }^{50}$ See e.g. G. Petrone, Quando le Muse parlavano latino. Studi su Plauto (Bologna, 2009).

${ }^{51} \mathrm{This}$ is 'a motif unattested in the extant palliata', as noted by Panayotakis (n. 41 [2005]), 138; cf. A. López López, Fabularum togatarum fragmenta (edición crítica) (Salamanca, 1983), 25-6, who has singled out the presence of this theme in some fragments of the togata playwright, without, however, providing further comment; cf. also J.T. Welsh, 'Quintilian's judgement of Afranius', $C Q 60$ (2010), 118-26, at 122: 'Quintilian was not thinking of pederasty at all, but rather of the dissipated and expensive type of love affair with disreputable women frequently seen in the palliata, affairs that threatened at the outset of those plays to destroy family finances and social standing, and provoked the ire of the older generation.' 
qui Afrani togatas appellat, sed et poetae, ut Horatius, qui ait 'uel qui praetextas uel qui docuere togatas'. togatarum fabularum species tot fere sunt quot et palliatarum. nam prima species est togatarum quae praetextatae dicuntur, in quibus imperatorum negotia agebantur et publica et reges Romani uel duces inducuntur, personarum dignitate et sublimitate tragoediis similes. praetextatae autem dicuntur, quia fere regum uel magistratuum qui praetexta utuntur in eius modi fabulas acta conprehenduntur. secunda species est togatarum quae tabernariae dicuntur et humilitate personarum et argumentorum similitudine comoediis pares, in quibus non magistratus regesue sed humiles homines et priuatae domus inducuntur, quae quidem olim quod tabulis tegerentur, communiter tabernae uocabantur. tertia species est fabularum Latinarum quae a ciuitate Oscorum Atella, in qua primum coeptae, appellatae sunt Atellanae, argumentis dictisque iocularibus similes satyricis fabulis Graecis. quarta species est planipedis, qui Graece dicitur mimus. ideo autem Latine planipes dictus $(\ldots) .^{52}$

The first sentence of Diomedes' passage (initio togatae ... cernebantur) is challenging, as it could be interpreted in various ways. Indeed, togatae could be considered either the subject of the verb or the predicate in the sentence. However, a comparison with similar constructions in Diomedes, in which the predicate always follows the subject (cf., for

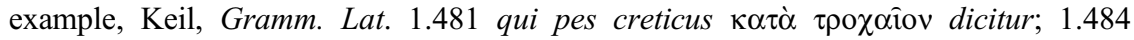
hexameter uersus epos dicitur; 1.507 iambicus scazon idem hipponacteus ab auctore dicitur; 1.524 alter pentameter iambicus dicitur) may suggest that the word togatae is the subject of the verb in the sentence, and the term comoediae, to be rendered as 'Greek comedies', the predicate. Togatae were once identified with the Greek term comoediae, because-as Diomedes reports later-omnia in publico honore confusa cernebantur. Diomedes' passage may testify to an initial sense of the word, diachronically specified as an 'ancient' use, denoting (1) a presumably comic Roman play vaguely (confusa) identified with comoedia. Diomedes then refers to further confusion over the term togata, which could apparently be used in three further senses: (2) as a general term denoting Roman tragedy and comedy together (in praetextatas et tabernarias diuidebantur); (3) or as a general term denoting a Roman genre comprising four different sub-genres, namely praetextata, tabernaria, Atellana and planipes (Diomedes' definition); or (4) as an imprecise synonym of tabernaria (pro tabernariis ... communis error), ${ }^{53}$ denoting a Roman comedy, which is different from Greek comedy, as Diomedes later emphasizes:

52 Transl. Manuwald (n. 9), 85 and 87: 'In the beginning togatae were just called comoediae, since everything that was publicly respected was perceived without distinctions. These togatae were later divided into praetextatae and tabernariae. Togatae is the name for those dramas that are written according to customs and dress of men in the toga, i.e. the Romans (for the toga is Roman), just as, according to Varro, Greek dramas are named after the dress in the same way and called palliatae. This term 'togata', even though it is a general expression, is nevertheless used in a special sense instead of tabernariae, not only by common error, which calls Afranius' plays togatae, but also by that of a poet, such as Horace, who says 'both those who produced praetextae and those who produced togatae'. There are basically as many forms of togata plays as there are also of palliata plays. For the first form of togatae are those plays that are called praetextatae, in which business of generals and public affairs are carried out and Roman kings or leaders are shown, similar to tragoediae in the dignity and elevation of the characters. And these are called praetextatae, since generally the deeds of kings and magistrates, who use the toga praetexta ('purple-bordered gown'), are presented in dramas of this type. The second form of togatae are those plays that are called tabernariae and are corresponding to comoediae in the humility of characters and the similarity of plot; in these dramas, instead of magistrates or kings, humble men and private dwellings are presented, which once upon a time were generally called tabernae ('huts') as they were covered with tabulae ('wooden tiles'). The third species of Latin plays are those that are called Atellanae after the Oscan community of Atella, in which they first began, in plot and jocular expressions similar to Greek satyr-plays. The fourth form is that of planipes, which is called mimus in Greek. But it is called planipes in Latin (...)'.

${ }^{53}$ On this, cf. also Brink (n. 26), 320, who discusses Diomedes' sentence in relation to the above-mentioned passage of Horace about the praetexta and the togata. He reports that Diomedes 
togata tabernaria a comoedia differt, quod in comoedia Graeci ritus inducuntur personaeque Graecae, Laches Sostrata; in illa uero Latinae. togatas tabernarias in scenam datauerunt praecipue duo, L. Afranius and C. Quintius. nam Terentius and Caecilius comoedias scripserunt. ${ }^{54}$

Diomedes himself seems to prefer meanings (2) and (3). Diomedes' attempt to improve theatrical nomenclature suggests how complex it was to understand Mid Republican dramatic genres. ${ }^{55}$ To the same extent, in the following section, I shall draw attention to Donatus' interests in the treatment of the togata.

\section{II.2. Donatus}

Donatus is likewise interested in the togata, and in several passages he uses the term with different meanings. He refers to the togata as a kind of Latin fabula, as we read in Comm. ad Ter. Ad. 7: (...) ut apud Graecos $\delta \rho \hat{\alpha} \mu \alpha$ sic apud Latinos generaliter fabula dicitur, cuius species sunt tragoedia, comoedia, togata, tabernaria, praetexta, crepidata, Atellana, $\mu \mathrm{i} \mu \mathrm{o} \varsigma$, Rhintonica ${ }^{56}$ Yet he makes mention of togata in comparison with palliata in terms of the onstage portrayal of slaves: while, in fact, the palliatae playwrights portrayed in their works slaves who were smarter than their masters, this changes in the togatae, as attested in Comm. ad Ter. Eun. 57 concessum est in palliata poetis comicis seruos dominis sapientiores fingere, quod idem in togata non fere licet. ${ }^{57}$ In Comm. ad Ter. Ad. 1.1, we find the usage of the term togata in relation to the name of the comedy Adelphoe: sed et Graeci nominis euphoniam perderet et praeterea togata uideretur. ${ }^{58}$ Furthermore, Donatus appears to consider the togata a genre distinct from both tragedy and comedy-and perhaps as a genre between the former and the latter-as in Excerpta de comoedia 5.4: comoediam apud Graecos dubium est quis primus inuenerit, apud Romanos certum: et comoediam et tragoediam et togatam primus Liuius Andronicus repperit. ${ }^{59}$ However, it must be said that he later clarifies that togata was probably a form of comedy (Excerpta de comoedia 6.1 and 6.5):

(6.1) fabula generale nomen est: eius duae primae partes tragoedia et comoedia. $<$ tragoedia $>$, si Latina argumentatio sit, praetexta dicitur. comoedia autem multas species habet: aut enim

'cites and criticizes the present verse of the Ars for the communis error of its nomenclature: praetextata, he pronounces, is a kind of togata, and $\mathrm{H}$. should have called his togata by the name of tabernaria'.

54 Transl. Manuwald (n. 9), 87 and 89: 'Togata tabernaria differs from comoedia in that in comoedia Greek customs are presented and Greek characters, like Laches or Sostrata, but in the former Latin ones. Togatae tabernariae for the stage were primarily produced by two poets, L. Afranius and C. Quinctius. For Terence and Caecilius wrote comoediae.' On the use of the terms fabula togata and fabula tabernaria, see L. Stankiewicz, 'Sources anciennes au sujet de togata', Eos 79 (1991), 33-44, at 33-6.

55 On the complexity of this passage, Lesky (n. 17), 358.

56 'As drama among the Greeks, so among the Latins fabula is used generally, the categories of which are tragedy, comedy, togata, tabernaria, praetexta, crepidata, Atellana, mime, Rhinthonica'. On the use of the word togata here, cf. also Lesky (n. 17), 364.

57 Transl. D. Feeney, Beyond Greek: The Beginnings of Latin Literature (Cambridge, MA and London, 2016), 181: 'comic poets in the palliata had the license to represent slaves as wiser than their masters, which is normally not allowed in the togata.'

58 'But it would also lose the euphony of the Greek name and furthermore would appear to be a togata'. Another interesting reference to the term togata, in opposition to palliata, is in Donat. Comm. ad Ter. Ph. 844: recte, quia palliata fabula est, non togata ('rightly so, because the play [sc. Phormio] is a palliata, not a togata').

59 'It is doubtful who first among the Greeks discovered comedy; it is certain among the Romans: Livius Andronicus first invented comedy, tragedy and the togata.' 
palliata est aut togata aut tabernaria aut Atellana aut mimus aut Rinthonica aut planipedia. (...) (6.5) comoediarum formae sunt tres: palliatae Graecum habitum referentes, togatae iuxta formam personarum habitum togarum desiderantes, quas nonnulli tabernarias uocant, Atellanae salibus et iocis compositae, quae in se non haberent nisi uetustatum elegantias. ${ }^{60}$

The term togatae is mentioned with palliatae and Atellanae as a species of comedy, in which characters wear the toga (iuxta ... desiderantes). However, people also referred to togatae using the term tabernariae ${ }^{61}$ — cf. Diomedes' passage discussed above (togatas autem ... pro tabernariis). The above-mentioned passages reveal how Donatus used the term togata by adopting, in different parts of his work, the same term but with several meanings: this denotes how such a theatrical category might have perhaps been a 'serious' hindrance for the grammarian.

\section{II.3. Ps.-Acro}

The same complexity of nomenclature is found in Ps.-Acro, who in the Schol. de Arte poet. 288 notes:

(...) qui praetextas fabulas fecerunt uel togatas, meruerunt nimium decus. praetextam quidam dicunt tragoediam, togatam autem comoediam. alii autem dicunt praetextam et togatam com $<0>$ edias esse, sed togatas, in quibus sunt Graeca argumenta, praetextas in quibus [sunt] Latina. ${ }^{62}$

Ps.-Acro comments on a verse of Horace (see also discussion above). What is striking in this comment is the reference to the various meanings of togata: Ps.-Acro mentions praetextae and togatae, differentiating the first, tragedy, from the second, comedy. Curiously, he then reports that, according to some people, praetexta and togata are both comedies: togatae are 'comedies with Greek subjects', while praetextae are 'comedies with Latin plots'. This testimony reveals a complex picture in the catalogue of dramatic genres. In particular, what may surprise modern readers is the reference to the togata as a comedy with Greek subjects; indeed, this has the potential to make radical changes to our understanding of this literary genre. Despite being an openly Roman genre, it portrayed onstage motifs associated with the Greek world, as may be confirmed by reading internal pieces of evidence. ${ }^{63}$ Furthermore, such testimony may provide an opportunity to highlight the boundaries between different genres, as well as the uncertain definition of another genre, the praetexta, which is surprisingly described as a (Latin) comedy rather than a (Latin) tragedy. To explain further how Ps.-Acro appears to adopt the term togata in a more generic sense, one may read the

60 Transl. Manuwald (n. 9), 89 and 91: 'Play is a general term: its two foremost types are tragoedia and comoedia. Tragoedia, if the plot is Latin, is called praetexta. Comoedia, however, has many forms: for it is either palliata or togata or Atellana or mimus or Rhinthonica or planipedia. (...) Of comedy there are three types: palliatae, reproducing Greek attire, togatae, requiring in addition to the type of characters the wearing of togas, which some call tabernariae, Atellanae, consisting of puns and jokes, which have nothing in them if not the elegance of age.'

${ }^{61}$ On this, see e.g. T. Guardì, 'La togata', Dioniso 61 (1991), 209-20, at 201-11; Manuwald (n. 3), $156-7$.

62 ' $(. .$.$) , those who wrote praetextae plays or togatae deserved much glory. Others say that$ praetexta (is) tragedy, togata instead is comedy. On the other hand, others say that praetexta and togata are comedies, but togatae (are those) in which there are Greek subjects, whereas praetextae (are those) in which (there are) Latin (subjects).'

${ }^{63}$ See, for instance, the presence of characters who have Greek names: Moschis in Afranius $136 \mathrm{R}^{3}$, Thais in Afranius' togata of the same name, and Nicasio in Afranius $189 \mathrm{R}^{3}$. 
Schol. in Ep. 2.1.79 Atta <tog>atarum scriptor tragoediarum et comoediarum fuit antiquus (...). ${ }^{64}$ The playwright Atta is labelled as an author of togatae tragedies and togatae comedies: presumably, Ps.-Acro uses the term togata here with the general meaning of 'play', ${ }^{65}$ which is linked to its specialization of tragoediae in the former case and comoediae in the latter.

\section{II.4. John the Lydian}

John the Lydian, in De magistratibus 1.40, also pays attention to the togata as a theatrical genre. He mentions Titinius, ${ }^{66}$ after discussing events of the late third century B.C.E., including Hannibal's invasion of Italy in 219 B.C.E. ${ }^{67}$ In doing so, he defines the togata as comedy:

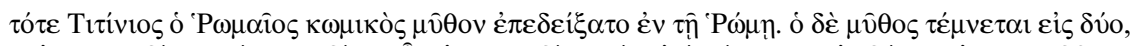

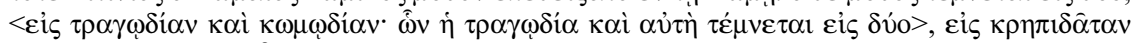

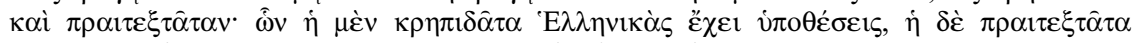

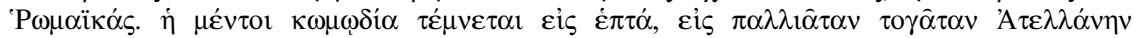

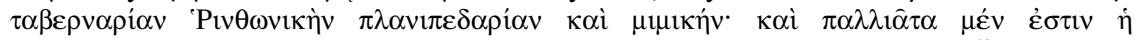

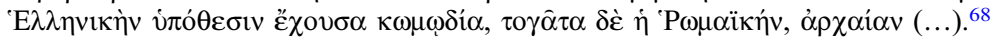

John the Lydian describes the complex nomenclature of Mid Republican literary genres. First, he explains the way in which the mythos is divided, that is, into tragedy and comedy, and after this he points out that tragedy is divided into the crepidata and the praetexta, that is, Latin tragedy with Greek and Roman themes respectively. He then lists seven types of comedy, and highlights the difference between the palliata (that

64 'Atta was an ancient writer of togatae tragedies and togatae comedies.'

${ }^{65}$ I take togata as an adjective qualifying both nouns because we do not have et after scriptor.

66 On the chronology of the togata playwright (along with Afranius and Atta), see, for example, J.T. Welsh, 'The dates of the dramatists of the fabula togata', HSPh 106 (2012), 125-53.

67 The passage, however, is problematic; its meaning is not clear, and the passage has been emended. J.D. Fuss, Joannis Laurentii Lydi Philadelpheni De Magistratibus reipublicae Romanae libri tres, nunc primum in lucem editi, et versione, notis indicibusque aucti (Paris, 1812) and I. Bekker, Ioannes Lydus ex recognitione Imannuelis Bekkeri (Bonn, 1837) altered the problematic

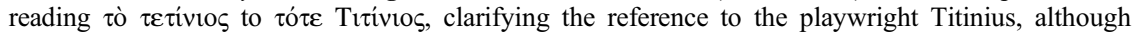
the Greek text reports that this author represented a more general $\mu \hat{v} \theta o v$ (i.e. 'representation') rather than specifically a $\tau$ o $\hat{\alpha} \tau \alpha \nu$, a term John the Lydian uses later in the same passage. R. Wünsch, Joannis Lydi De Magistratibus populi Romani libri tres (Leipzig, 1903), 34 accepted the emendation and took $\tau$ ó $\tau \varepsilon$ as referring to the events of 219 B.C.E. (discussed by John the Lydian in the previous passage), thus concluding that Titinius lived during that period. In contrast, C.J.C. Reuvens, Collectanea litteraria (Leiden, 1815), 27-9 and F.G. Ossanus, Analecta critica poesis Romanorum scaenicae reliquias illustrantia (Berlin, 1816), 44 rejected the suggestion of a reference to Titinius, arguing that the author mentioned in the passage would have been Livius Andronicus, the pioneer of Latin literature; they emended the text to $\tau$ ó $\varepsilon \varepsilon \Lambda i ß ı \varsigma$, and were followed by Neukirch (n. 3), 98-9 and N. Zorzetti, 'Problemi di letteratura latina arcaica', PP 30 (1975), 434-53, at 434-6; the emendation was considered likely by Welsh (n. 66), 129; I am inclined to agree with this emendation, because it is more accurate and logical.

${ }^{68}$ Transl. A.C. Bandy, Ioannes Lydus. On Powers or The Magistracies of the Roman State (Introduction, Critical Text, Translation, Commentary, and Indices) (Philadelphia, 1983), 61 and 63: 'At that time Titinius, the Roman comic poet, presented a play in Rome. A play is divided into two types: into tragedy and comedy, of which tragedy itself also is divided into two types: into crepidata and praetextata, of which the crepidata has Greek plots, while the praetextata has Roman plots. Comedy, however, is divided into seven types: into palliata, togata, Atellana, tabernaria, Rhinthonica, planipedaria, and miming. Palliata is a comedy which has a Greek plot, while togata is one which has a Roman plot of ancient type.' 
is, comedy with Greek themes) and the togata (that is, comedy with Roman themes), and considers all these as sub-comic forms. ${ }^{69}$

Here, we are clearly far away from the first attestations of the word togata, whose ancient authors - as stated above-were contemporaneous with the kind of performance they were writing about: John the Lydian, instead, merely repeats a set of scholarly clichés about ancient literary genres in the historical and cultural period in which he lives.

\section{II.5. Evanthius}

As a final example of the later grammarians and commentators who addressed the togata in their works, I quote Evanthius (De fabula 4.1$):^{70}$

illud uero tenendum est, post vé $\alpha v \kappa \omega \mu \omega \delta i ́ \alpha v$ Latinos multa fabularum genera protulisse, ut togatas ab scaenicis atque argumentis Latinis, praetextatas a dignitate personarum tragicarum ex Latina historia, Atellanas a ciuitate Campaniae, ubi actitatae sunt primae, Rinthonicas ab auctoris nomine, tabernarias ab humilitate argumenti ac stili, mimos ab diuturna imitatione uilium rerum ac leuium personarum. ${ }^{71}$

Here, the grammarian refers to a series of Latin dramas on stage. The first to be mentioned are the togatae, characterized as ab scaenicis atque argumentis Latinis. He then specifies that the praetextatae are based on tragic Latin history (that is, Latin tragedies), and the tabernariae on humilitate argumenti ac stili (that is, Latin comedies). Compared with Diomedes who considers the tabernaria to be a form of togata (as discussed above), Evanthius differentiates togata and tabernaria. The latter is not considered a subset of the former. In the nomenclature of Evanthius, togata appears to be a category which is neither a type of comedy (tabernaria) nor of tragedy (praetexta). Moreover, in this case attempts in giving nomenclature may depend on the way in which later grammarians and commentators considered the Roman Mid Republican dramatic genres with hindsight.

\section{FINAL REMARKS}

The main aim of this paper has been to re-investigate the little-studied dramatic genre of the togata, with a focus on its meaning. In particular, I have discussed the ancient attestations of the word togata, distinguishing ancient source-authors who probably watched togatae - and/or, in any case, knew what they were talking about-from later grammarians who aimed to improve the complex nomenclature relating to Mid Republican drama. Close analysis of the sources on the term togata challenges our knowledge of the Roman Republican drama. Ancient authors provide us with a variety

\footnotetext{
69 See further Lesky (n. 17), 365.

70 On the general structure of the De fabula, see G. Cupaiuolo, Evanzio. De fabula. Introduzione, testo critico, traduzione e note di commento (Naples, 1979), 14-87.

71 Transl. Manuwald (n. 9), 89: 'But what has to be borne in mind is that, after New Comedy, the Latins have produced many kinds of dramas, such as togatae based on Latin actors and plots, praetextatae based on characters of tragic dignity and stories from Latin history, Atellanae named after a township in Campania, where they were first acted [i.e. Atella], Rhinthonicae called after the author's name [i.e. Rhinthon], tabernariae with humble plot and style, mimi named after the constant imitation of cheap things and unimportant characters.'
} 
of meanings of the term togata, meanings which seem to be connected not only to its presupposed comic nature, as has thus far been taken for granted, but also to its sense as a generic dramatic category and a dramatic genre falling somewhere between tragedy and comedy. They hence testify to the permeability of dramatic genres in the Mid Republic. Such apparent heterogeneity could be due to the fact that ancient authors were freer to describe theatrical experiences without being conditioned by rigid conventions. Instead, in later periods, grammarians and commentators further obfuscated the very nomenclature of the dramatic genres that they were trying to elucidate. This includes our understanding of the togata.

Ancient authors and later grammarians and commentators reveal insights which surprise modern scholars and students of Roman drama, who are accustomed to categorizing a literary genre with specific labels; however, 'the past is a foreign country where they do things differently'. ${ }^{72}$

University of St Andrews

G.E. RALLO

ge6@st-andrews.ac.uk

eugenio.rallo@live.it

${ }^{72}$ I borrow here the famous opening sentence of the book of L.P. Hartley, The Go-Between (London, 1953). 